\title{
Ischemic stroke due to a calcified embolus from the mitral annular valve
}

Figure CT imaging
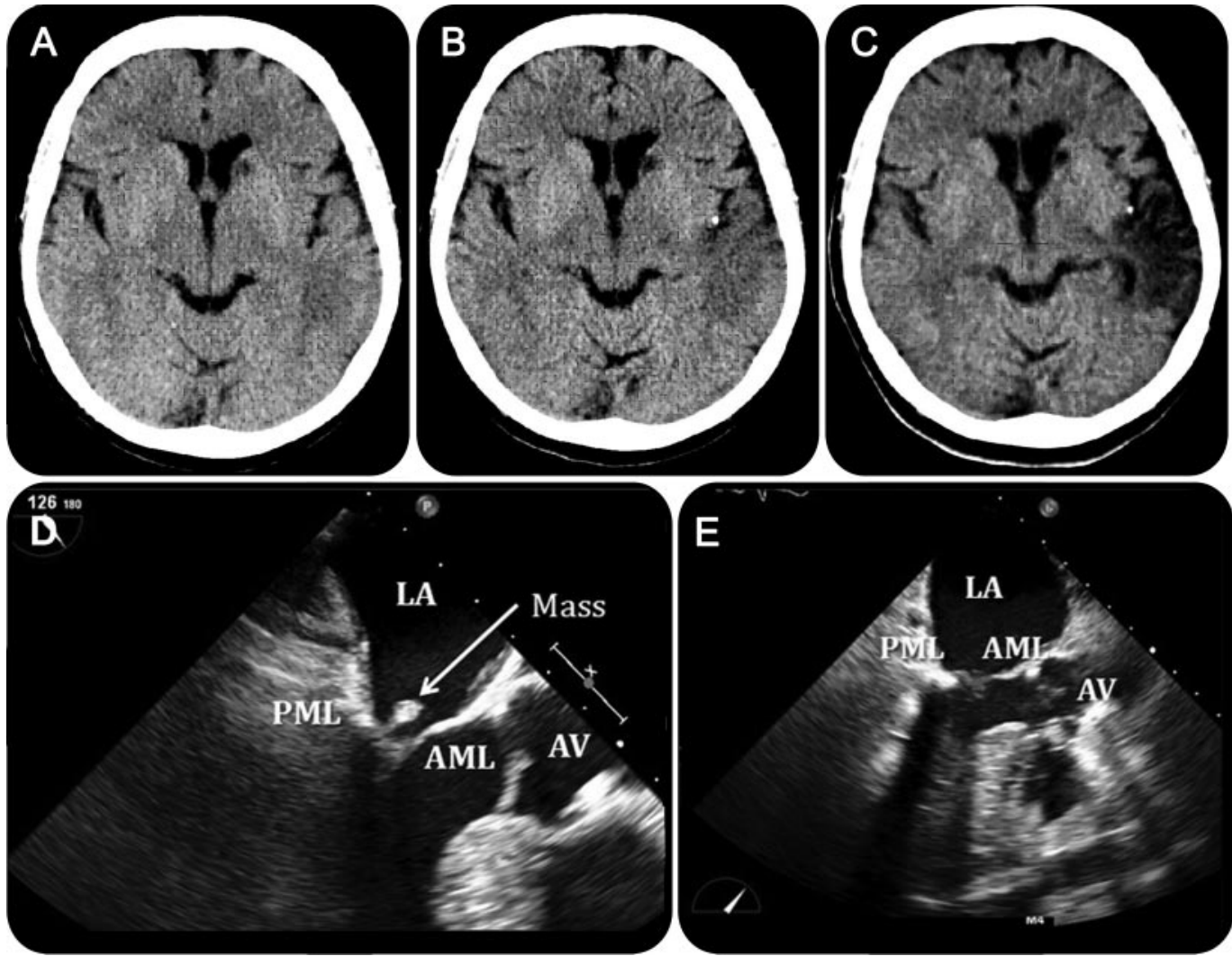

First CT (A) demonstrates an old lacunar unrelated infarction. Second CT (B) shows hyperacute stroke and small calcification in the left sylvian fissure, maintaining its position on the subsequent CT (C). First transesophageal echocardiography (TEE) (D) shows a hyperechoic mass attached to the posterior mitral leaflet, disappearing in second TEE (E).

A 68-year-old woman was admitted with an acute internuclear ophthalmoplegia. The first brain CT (figure, A) was unremarkable. Transesophageal echocardiography (TEE) demonstrated a mobile mass, attached to the posterior mitral valve leaflet (figure, D). The onset of sudden dysphasia prompted CT imaging, revealing a left temporo-parietal stroke and a small calcification in the left sylvian fissure (figure, B and C), compatible with the mitral valve mass on the first TEE. A repeat TEE showed absence of the mass (figure, E). The association between mitral annulus calcification and stroke has been described, ${ }^{1,2}$ but this case strongly supports a causal relationship based on sequential in vivo imaging.

M. Herskovitz, MD, G. Telman, MD, S. Carasso, MD, A. Symonovitz, MD, D. Goldsher, MD, Haifa, Israel

Author contributions: M. Herskovitz: design and conceptualization. G. Telman: design and conceptualization. S. Carasso: interpretation of data, revising of paper. A. Symonovitz: interpretation of data. D. Goldsher: interpretation of data, drafting and revising of the manuscript.

Disclosure: The authors report no disclosures.

Correspondence \& reprint requests to: dgoldsher@rambam.health.gov.il

\section{REFERENCES}

1. Adler Y, Fink N, Spector D, Wiser I, Sagie A. Mitral annulus calcification-a window to diffuse atherosclerosis of the vascular system. Atherosclerosis 2001;155:1-8.

2. Mohammadkhani M, Schaefer P, Koroshetz W, Hedley-Whyte ET. Mitral annulus calcareous brain emboli. Neurology 2000;54:817. 


\title{
Neurology
}

\author{
Ischemic stroke due to a calcified embolus from the mitral annular valve \\ M. Herskovitz, G. Telman, S. Carasso, et al. \\ Neurology 2012;78;931 \\ DOI 10.1212/WNL.0b013e31824c46f5
}

\section{This information is current as of March 19, 2012}

\section{Updated Information \& Services}

References

Subspecialty Collections

Permissions \& Licensing

\section{Reprints}

including high resolution figures, can be found at: http://n.neurology.org/content/78/12/931.full

This article cites 2 articles, 1 of which you can access for free at: http://n.neurology.org/content/78/12/931.full\#ref-list-1

This article, along with others on similar topics, appears in the following collection(s):

\section{All Cerebrovascular disease/Stroke}

http://n.neurology.org/cgi/collection/all_cerebrovascular_disease_strok e

\section{Cardiac}

http://n.neurology.org/cgi/collection/cardiac

CT

http://n.neurology.org/cgi/collection/ct

Embolism

http://n.neurology.org/cgi/collection/embolism

\section{Infarction}

http://n.neurology.org/cgi/collection/infarction

Information about reproducing this article in parts (figures,tables) or in its entirety can be found online at:

http://www.neurology.org/about/about_the_journal\#permissions

Information about ordering reprints can be found online:

http://n.neurology.org/subscribers/advertise

Neurology ${ }^{\circledR}$ is the official journal of the American Academy of Neurology. Published continuously since 1951, it is now a weekly with 48 issues per year. Copyright Copyright (? 2012 by AAN Enterprises, Inc.. All rights reserved. Print ISSN: 0028-3878. Online ISSN: 1526-632X.

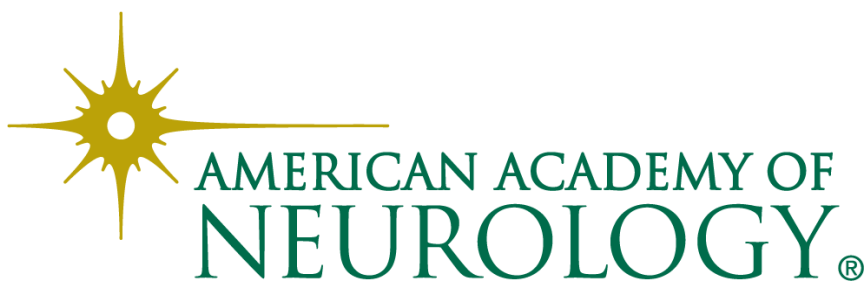

